The Structure, Prevalence, and Nature of Mass Belief Systems

Bert N. Bakker

Amsterdam School of Communication Research

University of Amsterdam, 1000 NG the Netherlands

Email: b.n.bakker@uva.nl

ORCID: 0000-0002-6491-5045

Yphtach Lelkes

Annenberg School of Communication Research

University of Pennsylvania, PA 19104

Email: ylelkes@upenn.edu

Chapter forthcoming in the Cambridge Handbook of Political Psychology (eds. Danny Osborne $\&$ Chris G. Sibley) 
The Structure, Prevalence, and Nature of Mass Belief Systems

Ideology is a central concept in political psychology. Since no book chapter could give the volumes of pages written on ideology its due justice, we attempt to give an overview of the scholarly debate's major themes. We have privileged breadth for depth, and, necessarily, miss some nuance - for examples of reviews of specific factors shaping ideology, see recent work by Bullock (2020a) and Federico and Malka (2018a).

Here, we first examine the ways in which ideology has been operationalized and discuss its distribution in the mass public. This is followed by a discussion of the top-down and bottom-up forces that shape citizens' ideology. Finally, we outline a selection of steps that we would welcome in the next generation of research on political ideology.

\section{The Structure of Ideology}

The meaning of ideology varies tremendously across time and field (Gerring, 1997; Knight, 2006). While there is a broad range in definitions of ideology across these writers and disciplines, modern political psychology generally adopts a definition similar to that of McClosky (1958) or (Converse, 1964): Ideologies are "systems of belief that are elaborate, integrated, and coherent, and justify the exercise of power, explain and judge historical events, identify political right and wrong, and set forth interconnections (causal and moral) between politics and other spheres of activity" McClosky (1958, p.362) or a "configuration of ideas and attitudes in which the elements are bound together by some form of constraint or functional interdependence" (Converse, 1964, p. 207).

Measuring such a system of beliefs is no easy task, however. The most common measure of political ideology is, by far, self-reported placement on a single left-right, or, in the US context, liberal-conservative scale. Defining ideology as a continuum from left to right dates back to the French Revolution, when members of the national assembly who supported the Ancien Regime sat to the right of the president, and revolutionaries sat to the left. These single-items scales have appeared on public opinion surveys since 
at least the 1950s (Converse, 1964) and grew in popularity after Downs (1957) used a variant to explain spatial distance in his "Economic Theory of Democracy."

However, self-reported ideology is an imprecise measure of ideology qua a system of beliefs for at least three reasons. First, responses to this measure may represent symbolic attachments rather than a system of belief (Conover \& Feldman, 1981; Malka \& Lelkes, 2010). Malka and Lelkes (2010), for instance, find that people identifying as a liberal or a conservative behave in a manner consistent with social identity theory: they are susceptible to normative (rather than informational) social influence as a result of group cues.

Second, there are substantial individual and contextual differences in the interpretation of the standard left-right or liberal-conservative scale, leading to low interpersonal comparability. For instance, Dalton (2010, p. 107) writes, "to a German blue-collar worker, left may still mean social welfare policies; to a young German college student it may mean environmental protection and issues of multiculturalism."

A third criticism of the left-right scale is that ideology is a multidimensional construct. Traditionally, the unidimensional left-right scale is meant to capture both support or opposition to social change and support or opposition to government intervention (Jost, Glaser, Kruglanski, \& Sulloway, 2003). While it is true that a uni-dimensional measure would capture the belief systems of politicians and political activists, at least in the United States (McCarty, Poole, \& Rosenthal, 2016) and in Europe (Van der Brug \& Van Spanje, 2009), the two dimensions are only weakly correlated in the mass public around the world (Malka, Lelkes, \& Soto, 2017).

An alternative approach to measuring ideology is to use policy positions as indicators of a latent ideology (See bottom of Figure 1). That is, we work backward, starting with the outputs of ideology to infer its structure. Using this approach, researchers have found that, for most people, ideology consists of (at least) two dimensions (Hillygus, 2011): one for cultural policies and one for economic policies. Malka et al. (2017) show that the correlation between these two dimensions varies greatly across countries. In most countries, economic and social conservatism are 
negatively correlated.

Furthermore, the strength and direction of this correlation are contingent on the information environment. For instance, in post-communist countries, where elites tend to group socially conservative with economically liberal attitudes, the correlation between these two dimensions is negative (Malka et al., 2017). In the United States, where political coalitions between economically conservative and socially conservative groups formed in the middle of the 20th century, the correlation is weakly positive.

Others have argued that two dimensions do not fully capture the structure of ideology. In particular, several studies claim that attitudes towards immigrants and national identity make up a third dimension of ideology in Europe and the United States (e.g., Kitschelt \& Rehm, 2014). Across Western European countries, Caughey, O'Grady, and Warshaw (2019) find that immigration and cultural ideology are very highly correlated $(\mathrm{r}=.83)$, and that social and economic $(\mathrm{r}=-.13)$ and immigration and economic ideology $(\mathrm{r}=-.10)$ are only weakly correlated. The high correlation between immigration and cultural ideology indicates that immigration and nationalism attitudes can likely be subsumed into the cultural dimension.

The structure of ideology outside of Western Europe and the United States is relatively unknown. While Malka et al. (2017) examine the correlation between two possible dimensions in countries around the world, the analysis does not tell us whether two dimensions accurately and exhaustively describe the belief systems in those countries. One recent exception is an analysis among the Chinese public Pan and Xu (2018, p.254-255), which finds that ideology is structured by three dimensions:

(i) preference for authoritarian institutions and conservative political values versus preference for democratic institutions and liberal political values, (ii) preference for promarket economic polices and nontraditional social values versus preference for state intervention in the economy and traditional social values, and (iii) preference for nationalism.

While most research that attempts to measure ideology using policy positions either sums across policy positions or utilizes a factor analytic technique, researchers 
have begun adopting the tools of social network analysis to understand the structure of ideology (Boutyline \& Vaisey, 2017; Brandt, Sibley, \& Osborne, 2019). This

methodology allows us to understand which political attitudes and identities (or nodes, in network analytic terms) "tie components from disparate regions of the belief system together and influence the network as a whole" (Brandt et al., 2019, p. 1353). For instance, both Boutyline and Vaisey (2017) and Brandt et al. (2019) find that symbolic identities are more central to belief systems than operational beliefs. While the network-based approach towards ideology is still in its infancy at the time of writing this chapter, we think it is a fruitful approach.

\section{The Distribution of Ideology}

Before delving into the nature of ideology, it is perhaps important to determine whether ideology exists in the heads of the public or only in the heads of the social scientists who study them.

A long tradition in political psychology holds that people are generally "innocent of ideology." In his agenda-setting work, Converse (1964) found that most Americans did not think in ideological terms and that most people did not hold a coherent set of policy attitudes. For instance, a person's attitudes on the government's role in health insurance only weakly predict his or her attitudes on the government's role in giving aid to the poor. Furthermore, a person's attitudes on an issue at one time point are not strongly correlated with his or her attitudes at a future time point. Recent work has replicated and extended much of Converse's findings. For instance, the majority of Americans who hold liberal policy views identify as conservative. Kalmoe (2020) finds that only the top-third most politically knowledgeable Americans hold "polar, coherent, durable, and potent" belief systems.

Relatedly, people also do not appear to exhibit "dynamic constraint." That is, there is not, in Converse's words, "functional interdependence" between attitudes. In a series of experiments, Coppock (2019) show that shifting attitudes on one policy to the right does not shift attitudes on another policy to the right. 
There has been significant pushback against Converse's conclusions. They argue that instability in attitudes is a result of measurement error rather than true opinion instability (Ansolabehere, Rodden, \& Snyder, 2008; Freeze \& Montgomery, 2015). In line with the measurement error hypothesis, using multiple items to create scales (Ansolabehere et al., 2008) or multi-trait multi-method confirmatory factor analysis yields (Freeze \& Montgomery, 2015) far more stable attitudes. For instance, while the correlation between any pair of issue attitudes is low ( $\mathrm{r}=.20$ or so), the correlation between issue batteries that purge measurement error by incorporating multiple questions on the same policy is quite high ( $\mathrm{r}=.80$ or so). Furthermore, the correlation between issue batteries and voting is relatively strong, demonstrating the power of ideology.

By far, most of the analysis of the ideological capacity of mass publics has focused on Americans. Linzer (2008) finds that in no country (out of the 44 he examined), do more than 5 percent of respondents give perfectly ideologically consistent responses to a set of six questions. However, we should not expect even the most ideological person to hold left-right consistent positions in all nations-rather, the correlation between issues depends on the political information environment. For instance, in post-communist countries, left economic policies go hand-in-hand with right cultural policies (Malka, Lelkes, \& Soto, 2019). While a comparative study of ideological reasoning is sorely needed, what should be held up as evidence (or not) of ideological reasoning should vary across context.

Although the ideological innocence debate is still ongoing, Americans seem increasingly constrained. One piece of evidence Converse (1964) used to defend his claim of ideological innocence was coding of the open-ended questions which asked respondents what they liked or disliked about various targets, e.g., Democrats and Republicans, on the American National Election Study. Converse (1964) derived a "levels of conceptualization" typology that categorized whether respondents gave ideological responses to these questions, finding that only 12 percent of the US electorate did so. Recently, Wattenberg (2019) demonstrated that, first, many 
respondents demonstrate a clear belief system in their responses, but don't use the terms "liberal" and "conservative." These respondents would not have been categorized as ideological by Converse, but, Wattenberg (2019) shows, these respondents are as politically knowledgeable, constrained and stable in their policy attitudes as those who do use the labels. Hence, Converse likely underestimated the percentage of Americans that think in ideological terms. Furthermore, Wattenberg (2019) finds that the percentage of the population that talk about politics in ideological terms has greatly increased. Today, 29 percent of ANES respondents use ideological concepts, and roughly 40 percent of respondents either use ideological concepts or show evidence of a belief system in their open-ended responses.

Additionally, recent studies demonstrate that ideological constraint has increased substantially since the 1970s (DellaPosta, 2020; Freeze \& Montgomery, 2015) and particularly after 2004 (Kozlowski \& Murphy, 2019). The rise in ideology in American mass publics is likely an elite-driven phenomenon (Levendusky, 2010). As political elites have become more polarized and provided clearer cues about "what goes with what," the mass public necessarily becomes more consistent and ideological.

\section{The origins of ideology}

Traditionally, political science research has emphasized how cultural, social, and environmental forces shape political ideology. Political psychologists have also studied bottom-up influences - such as genes, personality, and values - on ideology. We discuss both top-down and bottom-up influences on ideology and the possible interaction between the two. Figure 1 provides a stylized theoretical model of the top-down influences and bottom-up influences on ideology. We imagine the bottom-up influences as a funnel of causality and review both proximate and distal causes. We acknowledge that we discuss only a subset of all possible top-down and bottom-up factors. 
Figure 1. Model of the top-down and bottom-up factors shaping political ideology
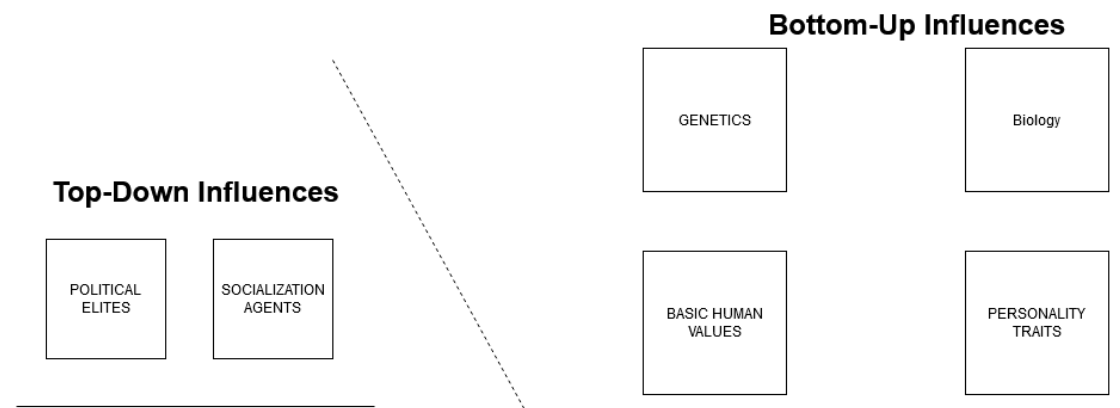

Inidividual-level moderators
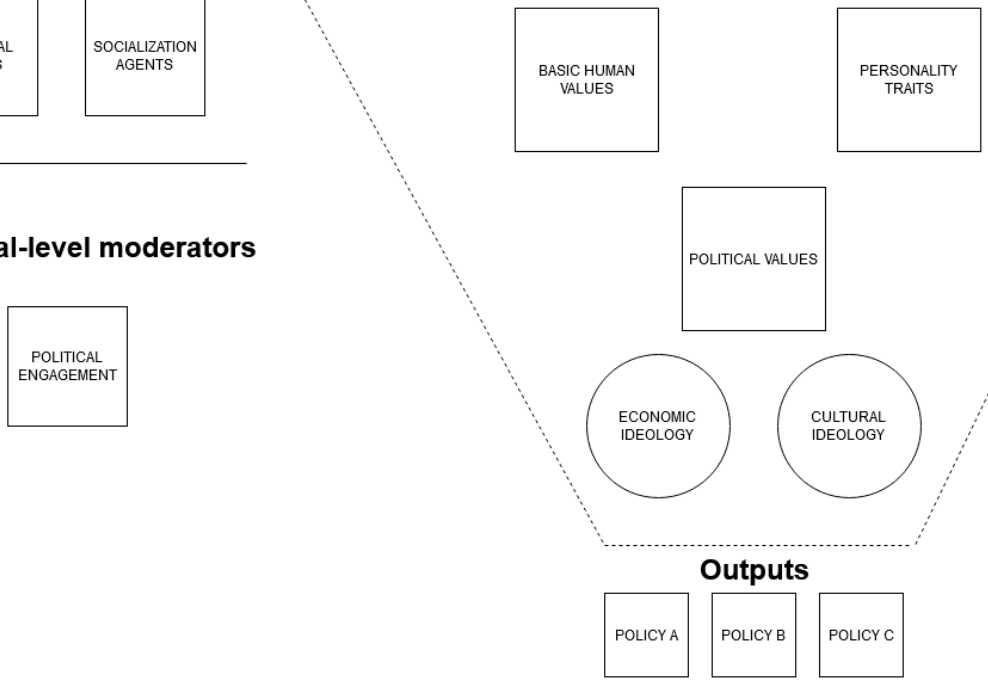

Top-down factors shaping ideology

\section{Political elites}

The most prominent top-down factor shaping ideology is by far the cues people take from political parties. Ever-expanding literature has shown that people in America and Europe rely on political parties to tell them which political positions to take (Aaroe, 2012; Bakker, Lelkes, \& Malka, 2020b; Slothuus, 2010). For instance, since

Donald Trump frequently shifted his political positions during the 2016 election, researchers were able to examine the effect of party cues in an ecologically valid way (Barber \& Pope, 2019). Trump supporters grew more favorable towards minimum wage increases when told that the candidate was also in favor, but less favorable when told he did not support such an increase.

Political elites may also shape ideology by making different attitudes salient. That is, elite influence may occur through priming-not persuasion. People may hold several considerations that could potentially affect belief systems (Zaller \& Feldman, 1992). By 
stressing certain policies, political elites strengthen the importance of an attitude in a person's belief system, ultimately making it more accessible (Lavine, Sullivan, Borgida, \& Thomsen, 1996) and stable. For instance, while many conservatives likely held anti-immigrant attitudes before the 2016 election, that node likely did not heavily constrain other attitudes until it was primed by Donald Trump.

Political elites may also shape ideology by making different attitudes salient. That is, elite influence may occur through priming-not persuasion. People may hold a number of considerations that could potentially affect belief systems (Zaller \& Feldman, 1992). By stressing certain policies, political elites strengthen the importance of an attitude in a person's belief system, ultimately making it more accessible (Lavine et al., 1996) and stable. For instance, while many conservatives likely held anti-immigrant attitudes before the 2016 election, that node likely did not heavily constrain other attitudes until it was primed by Donald Trump.

\section{Socialization agents: our families, old and new}

An extensive literature, dating back several decades, has argued that belief systems are acquired early in a person's life (Jennings \& Niemi, 1968). Much of this evidence rests on the empirical fact that the correlation between parents and children's political attitudes is fairly strong, especially if families are politically engaged (Jennings, Stoker, \& Bowers, 2009). Parents may influence their children's political belief through two routes: (1) directly exposing children through politics, e.g., by talking about politics around the dinner table or taking children to civic events or (2) by transferring their socio-economic status to their children, which carries with it class specific beliefs.

However, as people age, the correlation between their attitudes and their parents' attitudes weakens. Ironically, those adolescents with the most politically engaged parents are less likely to share their parents' political beliefs Dinas (2013, p. 581), as "those who are politically engaged are most likely to be exposed to new political stimuli in early adulthood".

Recent evidence has shown that children also influence their parents' political 
beliefs. For instance, having a daughter versus having a son increases left-wing gender attitudes among fathers (but not mothers) (Shafer \& Malhotra, 2011). This relationship is not limited to parents and children: having a sister, increases a brother's left-wing gender attitudes (Healy \& Malhotra, 2013).

The impact of families is not limited to one's immediate family but can be traced back many generations. Lelkes (2020) examines the relationship between the ancestral kinship structure of a person's ancestors and political beliefs. Groups that practiced medium- to large-scale agriculture required mechanisms to enforce cooperation and punish shirking. These groups adopted kinship structures such as endogamy, which produce in-group loyalty and transmitted certain values, such as respect for elders, which ensure efficient cooperation (Enke, 2019). Alternatively, groups which were more reliant on hunting and gathering require far flung-networks in case of a local disaster and developed far weaker kinship structures (Enke, 2019). To ensure efficient cooperation with outsiders, groups less reliant on agriculture instilled certain values, such as openness. These values (respect for elders and openness) are similar to those that past studies find structure political beliefs. Indeed, Lelkes (2020) finds that people and countries with a stronger ancestral kinship structure tend to support left-wing economic attitudes and right-wing cultural attitudes. While this perspective focuses on the cultural evolutionary roots of ideology, another area of research looks at evolution, per se (see Claessens et al, this volume).

Family are certainly not the only agent of socialization. Peers have a strong impact on political beliefs (Algan, Dalvit, Do, Le Chapelain, \& Zenou, 2015) as does schooling: secondary education increases right-wing economic ideology (Bullock, 2020b) and left-wing cultural ideology (Garrido, 2020). Media exposure has a strong influence (e.g., Martin \& Yurukoglu, 2017) as do various traumatic events, such as the Vietnam War (Erikson \& Stoker, 2011) or September 11 (Esses, Dovidio, \& Hodson, 2002). Many actors and events potentially influence a person's political belief system. A book chapter can certainly not do justice to all the work that has been written. 


\section{Bottom-up factors shaping ideology}

The bottom-up influences we outline in Figure 1 are ordered from more proximal (political values) to more distal factors (genes). The causal ordering is based upon our reading of the literature, but we acknowledge that this is a topic of debate. We start with the more proximal factors and work our way up to the more distal factors.

\section{Core political values}

Scholars have long held that "values-which may take such diverse forms as economic efficiency, social equality, individual freedom, crime control, national security, and racial purity - function as the backstops of belief systems" (Tetlock, 2000, p. 247). Political values are durable, abstract principles about desirable political end states. For instance, the left privileges equality, while the right privileges freedom and moral traditionalism. There is, however, little agreement as to which political values are important. Subsequently, analyses have been conducted in a piecemeal fashion-focusing on one or two values rather than the universe of political values (Goren, 2020). Nonetheless, political values have been associated with attitudes towards a variety of political beliefs, including social welfare, racial equality, and abortion (for an overview see, Connors, 2019).

However, some have challenged the notion that political values are exogeneous to ideology. First, Goren, Federico, and Kittilson (2009) showed that partisan cues influence political values. Connors (2019, p.1) shows that that political values are influenced by the social contexts and as such she concludes that "'political values' may be reflections of individuals' social contexts rather than values governing political behavior."

Basic human values. While scholars have posited at least 20 different "core" political values predict policy preferences (Goren, Schoen, Reifler, Scotto, \& Chittick, 2016), some have argued that these political values are themselves "expressions, in the political domain, of more basic personal values" (Schwartz et al., 2014, p. 899). These personal values are "transsituational beliefs about desirable end states and modes of 
conduct that can be rank-ordered in terms of personal importance" (Goren, 2020, p.1).

Schwartz (1994) derived ten personal values, of which there are four superordinate dimensions, satisfy both cognitive and motivational needs. In terms of the former, "Rather than evaluating every piece of information that matters for a choice, people fall back on diagnostic cues that perform as acceptable substitutes for complete information" (Goren et al., 2016, p. 982). Rather than knowing the details of a policy, for instance, a person only needs to know if it's linked to a basic human value. In terms of motivational needs, core human values allow people to express their identities. These basic core values, Schwartz et al. (2014) find, constrain political values.

Goren et al. (2016) argue that two of the four value domains (self-transcendence and conservation) constrain political beliefs as they regulate "how one relates socially to others and affects them" (Schwartz, 2012, p. 13). Openness to change and self-enhancement do not, as they regulate "how one expresses personal interests and characteristics."

\section{Personality traits}

Earlier theories of political behavior suggested that deeper-seated personality traits (or psychological needs) are relevant to understand political ideology (Campbell, Converse, Miller, \& Donald, 1960; McClosky, 1958). As much of this literature is reviewed by Federico et al (in this volume), we refer readers to that chapter, and make a few notes here:

An ever-growing number of studies in both psychology and political science continues to provide evidence that the psychological dispositions are associated with political ideology - (for a recent review see, Federico \& Malka, 2018b). Citizens adopt ideological positions that provide the best fit with the motives and needs rooted in their psychological dispositions (Jost, Federico, \& Napier, 2009). The association between psychological dispositions are theoretically a match between the content of the political issues and the motives and goals rooted in the psychological dispositions. Meta-analyses suggest that conservatives, who are more fearful, rigid, conventional, self-controlling, 
and orderly (Jost et al., 2003) resist changes and minimize insecurity. Liberals, who are more open-minded, imaginative, and impulsiveness, do not have this resistance to change and do not need to reduce insecurity to the same extent (Jost et al., 2003).

The association between personality and ideology might depend on the operationalization of ideology (Bakker, 2017; Duckitt \& Sibley, 2010; Feldman \& Johnston, 2014). Generally, the associations that are reported between psychological traits and left-right ideology generalize to cultural conservatism. There is, for instance, pretty consistent evidence that Openness is negatively associated with cultural conservatism, while conscientiousness is positively associated with cultural conservatism (Bakker, 2017; Duckitt \& Sibley, 2010).

When it comes to the psychological correlates of economic ideology, different perspectives existing. Hibbing, Smith, and Alford (2014, p.340) conclude that "psychological and biological characteristics are less relevant to economic issues . . . than they are to social issues." There are at least two alternative perspectives: (a) engagement conditions the association between broad open vs. closed trait and economic ideology and (b) some traits, like agreeableness and empathy are directly correlated with economic ideology. Malka, Soto, Inzlicht, and Lelkes (2014) theorized that those higher on the needs for security and certainty hold more left-wing economic ideology. But this association is weaker as engagement increases - for a similar argument see Johnston, Lavine, and Federico (2017, p.3).

Others find that Agreeableness - being caring, tender-minded and trusting (Bakker, 2017; Duckitt \& Sibley, 2010) and dispositional empathy (Feldman, Huddy, Wronski, \& Lown, 2020) are positively associated with liberal economic policy positions.

Going forward, we hope to see more research that disentangles which traits are directly related to economic ideology and for which traits this association is conditional upon factors such as engagement. 


\section{Our biology}

A relatively new paradigm in political science and psychology suggested that ideology might also have a biological root. Groundbreaking work by Oxley et al. (2008) published in Science showed that citizens with a conservative ideology - in particular who expressed a preference for tradition, hierarchies, and clear group boundaries experienced stronger physiological reactions to threatening stimuli than those with a liberal ideology. Extending the paradigm, those with stronger physiological responses to disgust express more conservative policy attitudes (Aarøe, Petersen, \& Arceneaux, 2017; Smith, Oxley, Hibbing, Alford, \& Hibbing, 2011). These studies suggest that ideology is associated with physiological responses to threat and disgust which Oxley et al. (2008, p.1667) see as evidence that ideology has a "built-in, almost 'automated' . . . response" which might suggest that conservative ideology is linked to a "negativity bias" (Hibbing et al., 2014).

A large preregistered replication in the United States using the exact same stimuli and comparable procedures as Oxley et al. (2008), by Bakker, Schumacher, Gothreau, and Arceneaux (2020) found no evidence for the assumed positive association between physiological threat sensitivity and conservative ideology. In the same study, Bakker, Schumacher, et al. (2020) also found no evidence that conservatives have a stronger physiological responses to disgust. The failure to replicate Oxley et al. (2008) does not stand on it own. Recently, Fournier, Soroka, and Nir (2021) also found no consistent evidence for a positive association between threat sensitivity and conservatism across 17 countries in five continents.

The failure to find evidence for the link between conservatism and physiological sensitivity to threat or disgust does not mean that there is no biological root of ideology. But it does mean that physiological responses to threat or disgust are probably not directly linked to ideology. The next generation of research will have to disentangle if and how physiological - and other "biological" responses - are linked to ideology (for a discussion, Bakker, Schumacher, et al., 2020). 


\section{Our Genes}

Social scientists have long posited that ideology is, in part, rooted in our DNA (for instance, Eaves \& Eysenck, 1974). But when Alford, Funk, and Hibbing (2005) showed - using data from the US and Australia - that ideology is partly heritable, this was followed by a substantive number of studies addressing the extent to which ideology - operationalized is different ways is heritable - for a review Dawes and Weinschenk (2020). A meta-analysis by Hatemi et al. (2014) - using 12,000 twin pairs from 9 different samples - showed that relative genetic influence on ideology accounts for 40 percent of the total variation. The genetic influence is on par with unique environmental influences and twice as large as shared environmental.

The logical question that arises is what explains why ideology is heritable. Hatemi et al. (2014, p.292) argue that there might be "genetic and environmental pathways by which genes influence the regulation of hormonal, cognitive and emotive states, which in turn influences the selection into, interpretation of, and reaction to, environmental stimuli relevant to political values, may eventually provide the necessary glue to combine the multitude of neurobiological influences on ideology captured across the sciences." One possibility is that personality is the missing link between genes and ideology. The few studies addressing this possibility show that there is a genetic overlap between personality and ideology (Hatemi \& Verhulst, 2015; Kandler, Bell, Shikishima, Yamagata, \& Riemann, 2015; Verhulst, Eaves, \& Hatemi, 2012). But there is a debate about what the genetic overlap of personality and ideology means. It could mean that: genes influence personality and personality influences ideology; (b) genes could also influence ideology and ideology could influence personality; (c) it could also suggest a reciprocal relationship whereby personality and ideology are both cause and consequence of each other; or (d) the same genetic component influences personality and ideology but this is happening largely independent from each other (Dawes \& Weinschenk, 2020). We agree with Dawes and Weinschenk (2020, p.175) that "additional research is needed in order to develop a better understanding of the pathways that connect genes to political ideology." 


\section{Next steps in this research agenda}

Here we outline some open-ended questions in the study of ideology and conclude with a call for the adoption of open science practices in the study of ideology.

\section{Question 1: How do top-down and bottom-up factors interact?}

A lot of the research on ideology - including our own - has focused on isolating one particular argument (or variable) in explaining ideology. We welcome more research that studies the interaction within bottom-up factors and interactions between bottom-up and top-down factors. There are promising examples within the bottom-up perspective exploring the interplay between genes, personality, and ideology (see, Dawes \& Weinschenk, 2020). Similarly, work on the individual level moderators of elite cues provide good examples of the interplay between top-down and bottom-up factors (Arceneaux \& Vander Wielen, 2017; Bakker, Lelkes, \& Malka, 2020b).

\section{Question 2: Are deeper-seated traits causing ideology?}

A majority of the research on the psychological roots of ideology that we discussed here relies upon cross-sectional studies, wherein self-reported personality (or values) is correlated with self-reported ideology. Yet, there is not much research that disentangles the extent to which psychological dispositions are indeed causing ideology. That said, there is a growing body of research that questions whether deeper-seated personality traits are indeed causing ideology.

One potentially powerful piece of evidence that personality is causing ideology is to provide proof that childhood personality is associated with ideology in adulthood. Block and Block (2006) found that children that were anxious, fearful, sensitive to guilt, and rigid in childhood were more likely to be self-reported conservatives in adulthood, while children that were expressive, autonomous, and self-reliant in childhood were more likely to be self-reported liberals in adulthood. Using a comparable design, Fraley, Griffin, Belsky, and Roisman (2012) conclude that liberal adults (at age 18) were more active and restless in childhood (at age 3.5), whereas conservative adults were more 
fearful in childhood. Yet, recent conceptual replications by Bakker and Fasching (2020) using two large cohort panels - one preregistered - from the United Kingdom, find no evidence that childhood personality is systematically associated with conservatism in adulthood. As such, the evidence of whether childhood personality is causing ideology is mixed.

One of the downsides of correlating childhood personality with ideology is that it is unlikely that ideology "appears" in adulthood. Studies that track both personality and ideology over a longer time are scarce. Osborne and Sibley (2020) conclude that openness is not causing ideology in a 7-year panel in New Zealand. Yet, Osborne and Sibley (2020) only focuses upon Openness but not Conscientiousness: the other trait within the Big Five framework consistently associated with conservatism. In a recent, preregistered, study, Bakker, Lelkes, and Malka (2020a) test the claim whether ideology is causing personality. Longitudinal data from the Netherlands, Germany, and the United States showed that personality causes ideology - as decades of personality-ideology has assumed. However, we also find that ideology is causing personality. As people become more conservative, they also self-report a more closed personality, broadly defined. In the same study Bakker, Lelkes, and Malka (2020a) prime politics (vs. a placebo-control) in two two-wave survey experiments and find that the association between previously assessed ideology and self-reported personality traits becomes stronger. The findings by Bakker, Lelkes, and Malka (2020a) align with other findings that egalitarian political ideology caused increases in empathy (Sidanius et al., 2013). And findings that political ideology exerted a causal influence on binding moral foundations (Hatemi, Crabtree, \& Smith, 2019; Smith, Alford, Hibbing, Martin, \& Hatemi, 2017). As such, a small body of studies suggests that personality is not only causing ideology but also that it is reciprocal.

To conclude, there is overwhelming evidence that self-reported psychological traits correlated with self-reported ideology. Yet, the extent to which deeper-seated personality traits are actually causing ideology is an open-ended question. In fact, some work suggests that the relationship is not as one-directional as we have assumed it is. A 
more dynamic conceptualization whereby personality influences ideology and ideology also influences personality would challenge many of the assumptions of the political psychology of ideology.

\section{Methodological improvements}

Much of the ideology literature relies on publicly available omnibus surveys like the American National Election Studies. Yet, time is costly in these surveys, and as a consequence, space is scarce. Therefore, survey designers utilize highly abbreviated indices of critical variables. However, this tradeoff may have implications for the conclusions we draw. For instance, Bakker and Lelkes (2018) showed that highly abbreviated measures of personality lead to an underestimation of the association between personality and ideology. Going forward, we urge researchers not to sell themselves short and ideally invest in measures of ideology - and other constructs of interest - that have acceptable psychometric properties. If this is not possible - which we understand - then we urge researchers to carefully consider whether measurement of ideology and related constructs could affect the conclusions they reach about the structure and nature of ideology (Ansolabehere et al., 2008; Bakker \& Lelkes, 2018).

There is increasing evidence accumulating that raises doubt whether ideology is caused by underlying deep-seated psychological traits, which raises serious questions about the bottom-up explanations of ideology. We welcome more, not less, research on this question. In particular, we welcome sufficiently powered, preregistered studies. Moreover, replications of seminal findings will be especially important as replications a crucial part of theoretical development (Chambers, 2019).

In general, we think it is important to replicate and preregister studies that test both the bottom-up and top-down forces shaping ideology. For instance, omnibus surveys like the ANES include many potential items to measure ideology and an increasing number of psychological dispositions - such as, but not limited too, authoritarianism, need for cognition, and the Big Five. Chambers (2019) documented, there is a "pressure" for researchers to report a meaningful (i.e., statistically significant) 
effects. Preregistering hypotheses and modeling strategies - ideally in registered reports - might help researchers to publish studies where they expected but failed to find an association between personality and ideology. Templates to preregister secondary data become available (Van den Akker et al., 2019) and have been applied in the study of political ideology (Bakker, Lelkes, \& Malka, 2020a).

\section{References}

Aaroe, L. (2012). When citizens go against elite directions: Partisan cues and contrast effects on citizens' attitudes. Party Politics, 18(2), 215-233.

Aarøe, L., Petersen, M. B., \& Arceneaux, K. (2017). The behavioral immune system shapes political intuitions: Why and how individual differences in disgust sensitivity underlie opposition to immigration. American Political Science Review, $111(2), 277-294$.

Alford, J. R., Funk, C. L., \& Hibbing, J. R. (2005). Are political orientations genetically transmitted? American political science review, 99(2), 153-167.

Algan, Y., Dalvit, N., Do, Q.-A., Le Chapelain, A., \& Zenou, Y. (2015). How Social Networks Shape Our Beliefs: A Natural Experiment among Future French Politicians. Working Paper, 0091 (June).

Ansolabehere, S., Rodden, J., \& Snyder, J. M. (2008). The strength of issues: Using multiple measures to gauge preference stability, ideological constraint, and issue voting. American Political Science Review, 102(2), 215-232.

Arceneaux, K., \& Vander Wielen, R. J. (2017). Taming Intuition. doi: $10.1017 / 9781108227643$

Bakker, B. N. (2017). Personality traits, income, and economic ideology. Political Psychology, 38(6), 1025-1041.

Bakker, B. N., \& Fasching, N. (2020). Childhood personality is not systematically associated with ideology in adulthood. working paper.

Bakker, B. N., \& Lelkes, Y. (2018). Selling ourselves short? how abbreviated measures of personality change the way we think about personality and politics. The 
Journal of Politics, 80(4), 1311-1325.

Bakker, B. N., Lelkes, Y., \& Malka, A. (2020a). Self-reported personality traits are endogenous to politics. working paper.

Bakker, B. N., Lelkes, Y., \& Malka, A. (2020b). Understanding partisan cue receptivity: Tests of predictions from the bounded rationality and expressive utility perspectives. The Journal of Politics, 82(3), 1061-1077.

Bakker, B. N., Schumacher, G., Gothreau, C., \& Arceneaux, K. (2020). Conservatives and liberals have similar physiological responses to threats. Nature Human Behaviour, 613-621.

Barber, M., \& Pope, J. C. (2019). Does Party Trump Ideology? Disentangling Party and Ideology in America. American Political Science Review, 113(1), 38-54. doi: $10.1017 / \mathrm{S} 0003055418000795$

Block, J., \& Block, J. H. (2006). Nursery school personality and political orientation two decades later. Journal of Research in Personality, 40(5), 734-749.

Boutyline, A., \& Vaisey, S. (2017). Belief Network Analysis: A Relational Approach to Understanding the Structure of Attitudes. American Journal of Sociology, 122(5), 1371-1447. doi: 10.1086/691274

Brandt, M. J., Sibley, C. G., \& Osborne, D. (2019). What Is Central to Political Belief System Networks? Personality and Social Psychology Bulletin, 45(9), 1352-1364. doi: $10.1177 / 0146167218824354$

Bullock, J. G. (2020a). Education and Attitudes toward Redistribution in the United States. British Journal of Political Science, 1-21. doi: $10.1017 /$ S0007123419000504

Bullock, J. G. (2020b). Education and attitudes toward redistribution in the united states. British Journal of Political Science, 1-21.

Campbell, A., Converse, P. E., Miller, W. E., \& Donald, E. (1960). Stokes. the american voter. Ann Arbor, MI: University of Michigan Press.

Caughey, D., O'Grady, T. O., \& Warshaw, C. (2019). Policy ideology in European Mass Publics, 1981-2016. American Political Science Review, 113(3), 674-693. 
doi: $10.1017 / \mathrm{S} 0003055419000157$

Chambers, C. (2019). The seven deadly sins of psychology: A manifesto for reforming the culture of scientific practice. Princeton University Press.

Connors, E. C. (2019). The social dimension of political values. Political Behavior, $1-22$.

Conover, P. J., \& Feldman, S. (1981). The origins and meaning of liberal/conservative self-identifications. American Journal of Political Science, 25(4), 617-645.

Converse, P. E. (1964). The nature of belief systems in mass politics. In D. Apter (Ed.), Ideology and discontent (pp. 206-261). New York: The Free Press of Glencoe.

Coppock, A. (2019). Generalizing from Survey Experiments Conducted on Mechanical Turk: A Replication Approach. doi: 10.1017/psrm.2018.10

Dalton, R. J. (2010). Ideology, partisanship, and democratic development. In Comparing democracies: Elections and voting in the 21st century. doi: 10.4135/9781446288740.n7

Dawes, C. T., \& Weinschenk, A. C. (2020). On the genetic basis of political orientation. Current Opinion in Behavioral Sciences, 34, 173-178.

DellaPosta, D. (2020). Pluralistic Collapse: The "Oil Spill" Model of Mass Opinion Polarization. American Sociological Review. doi: 10.1177/0003122420922989

Dinas, E. (2013). Why does the apple fall far from the tree? How early political socialization prompts parent-child dissimilarity. British Journal of Political Science, 44(4), 827-852. doi: 10.1017/S0007123413000033

Downs, A. (1957). An Economic Theory of Democracy (Vol. 13) (No. 1). Harper. doi: $10.2307 / 444355$

Duckitt, J., \& Sibley, C. G. (2010). Personality, ideology, prejudice, and politics: A dual-process motivational model. Journal of personality, 78(6), 1861-1894.

Eaves, L. J., \& Eysenck, H. J. (1974). Genetics and the development of social attitudes. Nature, 249(5454), 288-289.

Enke, B. (2019). Kinship, Cooperation, and the Evolution of Moral Systems*. The Quarterly Journal of Economics, 134(2), 953-1019. doi: 10.1093/qje/qjz001 
Erikson, R. S., \& Stoker, L. (2011). Caught in the draft: The effects of vietnam draft lottery status on political attitudes. American Political Science Review, 105(2), 221-237. Retrieved from http://journals.cambridge.org/action/ displayFulltext?type=6\&f $i d=8278956 \& j$ id=PSR\&volumeId=105\&issueId= 02\&aid=8278955\&fulltextType=RA\&fileId=S0003055411000141\#rfh1 doi: $10.1017 / \mathrm{S} 0003055411000141$

Esses, V. M., Dovidio, J. F., \& Hodson, G. (2002). Public Attitudes Toward Immigration in the United States and Canada in Response to the September 11, 2001 "Attack on America". Analyses of Social Issues and Public Policy, 2(1), 69-85. doi: 10.1111/j.1530-2415.2002.00028.x

Federico, C. M., \& Malka, A. (2018a). The Contingent, Contextual Nature of the Relationship Between Needs for Security and Certainty and Political Preferences: Evidence and Implications. Political Psychology, 39, 3-48. doi: $10.1111 /$ pops. 12477

Federico, C. M., \& Malka, A. (2018b). The contingent, contextual nature of the relationship between needs for security and certainty and political preferences: Evidence and implications. Political Psychology, 39, 3-48.

Feldman, S., Huddy, L., Wronski, J., \& Lown, P. (2020). The interplay of empathy and individualism in support for social welfare policies. Political Psychology, 41(2), 343-362.

Feldman, S., \& Johnston, C. (2014). Understanding the determinants of political ideology: Implications of structural complexity. Political Psychology, 35(3), $337-358$.

Fournier, P., Soroka, S., \& Nir, L. (2021). Negativity biases and political ideology: A comparative test across 17 countries. American Political Science Review.

Fraley, R. C., Griffin, B. N., Belsky, J., \& Roisman, G. I. (2012). Developmental antecedents of political ideology: A longitudinal investigation from birth to age 18 years. Psychological science, 23(11), 1425-1431.

Freeze, M., \& Montgomery, J. M. (2015). Static Stability and Evolving Constraint: 
Preference Stability and Ideological Structure in the Mass Public. American Politics Research, 44(3), 415-447. doi: 10.1177/1532673X15607299

Garrido, N. R. (2020). Can Education Reduce Traditional Gender Role.

Gerring, J. (1997). Ideology: A definitional analysis. doi: 10.1177/106591299705000412

Goren, P. (2020). Values and Public Opinion. In Oxford research encyclopedia of politics (pp. 1-29). doi: 10.1093/acrefore/9780190228637.013.954

Goren, P., Federico, C. M., \& Kittilson, M. C. (2009). Source cues, partisan identities, and political value expression. American Journal of Political Science, 53(4), 805-820.

Goren, P., Schoen, H., Reifler, J., Scotto, T., \& Chittick, W. (2016). A Unified Theory of Value-Based Reasoning and U.S. Public Opinion. Political Behavior, 38(4), 977-997. doi: 10.1007/s11109-016-9344-x

Hatemi, P. K., Crabtree, C., \& Smith, K. B. (2019). Ideology justifies morality: Political beliefs predict moral foundations. American Journal of Political Science, 63(4), 788-806.

Hatemi, P. K., Medland, S. E., Klemmensen, R., Oskarsson, S., Littvay, L., Dawes, C. T., ... others (2014). Genetic influences on political ideologies: Twin analyses of 19 measures of political ideologies from five democracies and genome-wide findings from three populations. Behavior genetics, 44(3), 282-294.

Hatemi, P. K., \& Verhulst, B. (2015). Political attitudes develop independently of personality traits. PloS one, 10(3).

Healy, A., \& Malhotra, N. (2013). Childhood socialization and political attitudes: Evidence from a natural experiment. Journal of Politics, 75 (4), 1023-1037. doi: $10.1017 / \mathrm{S} 0022381613000996$

Hibbing, J. R., Smith, K. B., \& Alford, J. R. (2014). Differences in negativity bias underlie variations in political ideology. Behaviour and Brain Sciences.

Hillygus, D. S. (2011). The evolution of election polling in the United States. Public Opinion Quarterly, 75 (5 SPEC. ISSUE), 962-981. doi: 10.1093/poq/nfr054

Jennings, M. K., \& Niemi, R. G. (1968). The Transmission of Political Values from 
Parent to Child. American Political Science Review, 62(1), 169-184. doi: $10.1017 / \mathrm{S} 0003055400115709$

Jennings, M. K., Stoker, L., \& Bowers, J. (2009). Politics across generations: Family transmission reexamined. Journal of Politics. doi: 10.1017/S0022381609090719

Johnston, C. D., Lavine, H. G., \& Federico, C. M. (2017). Open versus closed: Personality, identity, and the politics of redistribution. Cambridge University Press.

Jost, J. T., Federico, C. M., \& Napier, J. L. (2009). Political ideology: Its structure, functions, and elective affinities. Annual review of psychology, 60, 307-337.

Jost, J. T., Glaser, J., Kruglanski, A. W., \& Sulloway, F. J. (2003). Political conservatism as motivated social cognition. Psychological bulletin, 129(3), 339.

Kalmoe, N. P. (2020). Uses and abuses of ideology in political psychology. Political Psychology.

Kandler, C., Bell, E., Shikishima, C., Yamagata, S., \& Riemann, R. (2015). Genetic foundations of attitude formation. Emerging trends in the social and behavioral sciences: An interdisciplinary, searchable, and linkable resource, 1-21.

Kitschelt, H., \& Rehm, P. (2014). Occupations as a Site of Political Preference Formation. Comparative Political Studies. doi: 10.1177/0010414013516066

Knight, K. (2006). Transformations of the concept of ideology in the twentieth century. American Political Science Review, 100(4), 619-626. doi: $10.1017 / \mathrm{S} 0003055406062502$

Kozlowski, A., \& Murphy, J. P. (2019). Issue Alignment and Partisanship in the American Public: Revisiting the'Partisans without Constraint'Thesis.

Lavine, H., Sullivan, J. L., Borgida, E., \& Thomsen, C. J. (1996). The relationship of national and personal issue salience to attitude accessibility on foreign and domestic policy issues. Political Psychology, 293-316.

Lelkes, Y. (2020). Ancestral Kinship and the Origins of Ideology.

Levendusky, M. S. (2010). Clearer cues, more consistent voters: A benefit of elite polarization. Political Behavior, 32(1), 111-131. doi: 10.1007/s11109-009-9094-0 
Linzer, D. A. (2008). The structure of mass ideology and its consequences for democratic governance. ProQuest Dissertations and Theses, 170. Retrieved from https://search.proquest. com/docview/304655873?accountid=35812

Malka, A., \& Lelkes, Y. (2010). More than ideology: Conservative-liberal identity and receptivity to political cues. Social Justice Research, 23(2-3), 156-188.

Malka, A., Lelkes, Y., \& Soto, C. J. (2017). Are Cultural and Economic Conservatism Positively Correlated? A Large-Scale Cross-National Test. British Journal of Political Science, 49(3), 1-25. doi: 10.1017/s0007123417000072

Malka, A., Lelkes, Y., \& Soto, C. J. (2019). Are Cultural and Economic Conservatism Positively Correlated? A Large-Scale Cross-National Test. British Journal of Political Science, 49(3), 1045-1069. doi: 10.1017/S0007123417000072

Malka, A., Soto, C. J., Inzlicht, M., \& Lelkes, Y. (2014). Do needs for security and certainty predict cultural and economic conservatism? a cross-national analysis. Journal of Personality and Social Psychology, 106(6), 1031.

Martin, G. J., \& Yurukoglu, A. (2017). Bias in cable news: Persuasion and polarization. American Economic Review, 107(9), 2565-99.

McCarty, N., Poole, K. T., \& Rosenthal, H. (2016). Polarized America: The dance of ideology and unequal riches. mit Press.

McClosky, H. (1958). Conservatism and personality. American Political Science Review, 52(1), 27-45.

Osborne, D., \& Sibley, C. G. (2020). Does openness to experience predict changes in conservatism? a nine-wave longitudinal investigation into the personality roots to ideology. Journal of Research in Personality, 103979.

Oxley, D. R., Smith, K. B., Alford, J. R., Hibbing, M. V., Miller, J. L., Scalora, M., ... Hibbing, J. R. (2008). Political attitudes vary with physiological traits. science, 321(5896), 1667-1670.

Pan, J., \& Xu, Y. (2018). China's ideological spectrum. Journal of Politics, 80(1), 254-273. doi: $10.1086 / 694255$

Schwartz, S. H. (1994). Are There Universal Aspects in the Structure and Contents of 
Human Values? Journal of Social Issues, 50(4), 19-45. doi:

10.1111/j.1540-4560.1994.tb01196.x

Schwartz, S. H. (2012). An Overview of the Schwartz Theory of Basic Values. Online Readings in Psychology and Culture. doi: 10.9707/2307-0919.1116

Schwartz, S. H., Caprara, G. V., Vecchione, M., Bain, P., Bianchi, G., Caprara, M. G., ... Zaleski, Z. (2014). Basic Personal Values Underlie and Give Coherence to Political Values: A Cross National Study in 15 Countries. Political Behavior, 36(4), 899-930. doi: 10.1007/s11109-013-9255-z

Shafer, E. F., \& Malhotra, N. (2011). The effect of a child's sex on support for traditional gender roles. Social Forces, 90(1), 209-222. doi: 10.1093/sf/90.1.209

Sidanius, J., Kteily, N., Sheehy-Skeffington, J., Ho, A. K., Sibley, C., \& Duriez, B. (2013). You're inferior and not worth our concern: The interface between empathy and social dominance orientation. Journal of personality, 81(3), 313-323.

Slothuus, R. (2010). When can political parties lead public opinion? evidence from a natural experiment. Political Communication, 27(2), 158-177.

Smith, K. B., Alford, J. R., Hibbing, J. R., Martin, N. G., \& Hatemi, P. K. (2017). Intuitive ethics and political orientations: Testing moral foundations as a theory of political ideology. American Journal of Political Science, 61(2), 424-437.

Smith, K. B., Oxley, D., Hibbing, M. V., Alford, J. R., \& Hibbing, J. R. (2011). Disgust sensitivity and the neurophysiology of left-right political orientations. PloS one, 6(10), e25552.

Tetlock, P. E. (2000). Coping with Trade-Offs: Psychological Constraints and Political Implications. Retrieved from https://books.google.com/books?hl=nl\&lr=\&id=oXC40W4HmaIC\&pgis=1 doi: 10.1017/CBO9780511805813.011

Van den Akker, O., Weston, S. J., Campbell, L., Chopik, W. J., Damian, R. I., Davis-Kean, P., .. others (2019). Preregistration of secondary data analysis: A template and tutorial.

Van der Brug, W., \& Van Spanje, J. (2009). Immigration, europe and the 'new'cultural 
dimension. European Journal of Political Research, 48(3), 309-334.

Verhulst, B., Eaves, L. J., \& Hatemi, P. K. (2012). Correlation not causation: The relationship between personality traits and political ideologies. American journal of political science, $56(1), 34-51$.

Wattenberg, M. P. (2019). The Changing Nature of Mass Belief Systems: The Rise of Concept and Policy Ideologues. Critical Review, 31(2), 198-229. doi: $10.1080 / 08913811.2019 .1690223$

Zaller, J., \& Feldman, S. (1992). A simple theory of the survey response: Answering questions versus revealing preferences. American journal of political science, $579-616$. 